\title{
A Novel Phosphate Chemosensor Utilizing Anion-Induced Fluorescence Change
}

\author{
Jen-Hai Liao, Chao-Tsen Chen, and Jim-Min Fang* \\ Department of Chemistry, National Taiwan University, \\ Taipei, Taiwan 106, Republic of China
}

jmfang@ccms.ntu.edu.tw

Received November 30, 2001

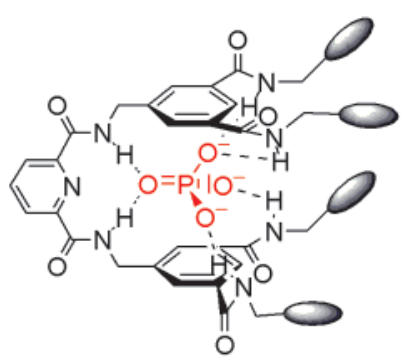

represents 1-pyrene

The neutral receptor $N, N$-bis $\{3,5$-di[(1-pyrenylmethyl)carbamoyl]benzyl $\}$ pyridine-2,6-dicarbamide (2) provides a pseudo-tetrahedron cleft and multiple hydrogen bondings to form a 1:1 complex with phosphate ion in a highly selective manner, by comparison with other anions $\left(\mathrm{F}^{-}\right.$, $\mathrm{Cl}^{-}$, $\mathrm{Br}^{-}, \mathrm{SCN}^{-}, \mathrm{AcO}^{-}, \mathrm{NO}_{3}{ }^{-}, \mathrm{ClO}_{4}^{-}$, and $\left.\mathrm{HSO}_{4}^{-}\right)$. The binding strength can be inferred from the emission intensity ratio of the pyrene monomer $\left(\lambda_{\max } 377 \mathrm{~nm}\right)$ to the excimer $\left(\lambda_{\max } 477 \mathrm{~nm}\right)$. Fluorescence titration, X-ray analysis, and NMR studies support a proposed complexation model.

As a result of the biological and environmental significance of phosphate ions, selective recognition and sensing of phosphates are of great importance in the modern host-guest chemistry. ${ }^{1}$ However, the inherent tetrahedral structure of phosphate ion also disposes a challenging problem for the design of effective receptors. ${ }^{2}$ Several synthetic receptors bearing polyaza, ${ }^{1 \mathrm{c}, \mathrm{d}, 3}$ thiourea, ${ }^{4 \mathrm{a}-\mathrm{c}}$ urea, ${ }^{4 \mathrm{~d}, \mathrm{e}}$ amide $^{1 \mathrm{a}, 5}$ and quanidinium $^{1 \mathrm{~b}, 6}$ moieties have been demonstrated to bind or transport phosphates. ${ }^{7}$ The neutral receptors of thiourea and amide types are particularly interesting, because the transport

(1) (a) Beer, P. D. Acc. Chem. Res. 1998, 31, 71-80. (b) Watanabe, S.; Onogawa, O.; Komatsu, Y.; Yoshida, K. J. Am. Chem. Soc. 1998, 120, 229-230. (c) Beer, P. D.; Cadman, J.; Lloris, J. M.; Martínez-Máñez, R.; Padilla, M. E.; Pardo, T.; Smith, D. K.; Soto, J. J. Chem. Soc., Dalton Trans. 1999, 127-133. (d) Beer, P. D.; Cadman, J. New J. Chem. 1999, 23, 347-349. (e) Anzenbacher, P., Jr.; Jursíková, K.; Sessler, J. L. J. Am. Chem. Soc. 2000, 122, 9350-9351. (f) Miyaji, H.; Sessler, J. L. Angew. Chem., Int. Ed. 2001, 40, 154-157. (g) Sancenón, F.; Descalzo, A. B.; Martínez-Máñez, R.; Miranda, M. A.; Soto, J. Angew. Chem., Int. Ed. 2001, 40, 2640-2643.

(2) Schmidtchen, F. P.; Berger, M. Chem. Rev. 1997, 97, 1609-1646.

(3) Marecek, J. F.; Fischer, P. A.; Burrows, C. J. Tetrahedron Lett. 1988, $29,6231-6234$ of phosphates through cell membrane is also regulated by neutral binding proteins. We report herein two artificial neutral phosphate receptors $\mathbf{1}$ and $\mathbf{2}$ with multiple amide

(4) (a) Nishizawa, S.; Bühlmann, P.; Iwao, M.; Umezawa, Y. Tetrahedron Lett. 1995, 36, 6483-6486. (b) Bühlmann, P.; Nishizawa, S.; Xiao, K. P.; Umezawa, Y. Tetrahedron 1997, 53, 1647-1654. (c) Sasaki, S.; Mizuno, M.; Naemura, K.; Tobe, Y. J. Org. Chem. 2000, 65, 275-283. (d) Xie, H.; Yi, S.; Yang, X.; Wu, S. New J. Chem. 1999, 23, 1105-1110. (e) SnellinkRuël, B. H. M.; Antonisse, M. M. G.; Engbersen, J. F. J.; Timmerman, P.; Reinhoudt, D. N. Eur. J. Org. Chem. 2000, 165-170.

(5) (a) Raposo, C.; Pérez, N.; Almaraz, M.; Mussons, M. L.; Caballero, M. C.; Morán, J. R. Tetrahedron Lett. 1995, 36, 3255-3258. (b) Beer, P. D.; Graydon, A. R.; Sutton, L. R. Polyhedron 1996, 15, 2457-2461. (c) Szemes, F.; Hesek, D.; Chen, Z.; Dent, S. W.; Drew, M. G. B.; Goulden, A. J.; Graydon, A. R.; Grieve, A.; Mortimer, R. J.; Wear, T.; Weightman, J. S.; Beer, P. D. Inorg. Chem. 1996, 35, 5868-5879. (d) Beer, P. D.; Szemes, F.; Balzani, V.; Salà, C. M.; Drew, M. G. B.; Dent, S. W.; Maestri, M. J. Am. Chem. Soc. 1997, 119, 11864-11875. (e) Beer, P. D.; Timoshenko, V.; Maestri, M.; Passaniti, P.; Balzani, V. Chem. Commun. 1999, 1755-1756. (f) Cooper, J. B.; Drew, M. G. B.; Beer, P. D. J. Chem. Soc., Dalton Trans. 2000, 2721-2728. (g) Hossain, Md. A.; Llinares, J. M.; Powell, D.; Bowman-James, K. Inorg. Chem. 2001, 40, 2936-2937.

(6) (a) Galán, A.; de Mendoza, J.; Toiron, C.; Bruix, M.; Deslongchamps, G.; Rebek, J., Jr. J. Am. Chem. Soc. 1991, 113, 9424-9425. (b) Ariga, K.; Anslyn, E. V. J. Org. Chem. 1992, 57, 417-419. (c) Müller, G.; Dürner, G.; Bats, J. W.; Göbel, M. W. Liebigs Ann. Chem. 1994, 1075-1092. 
Scheme 1. Synthesis of Compounds $1-\mathbf{3}^{a}$<smiles>N#Cc1cc(C(=O)O)cc(C(=O)O)c1</smiles><smiles>C#CC</smiles><smiles>[R]NC(=O)c1cc(CN)cc(C(=O)N[R])c1</smiles>

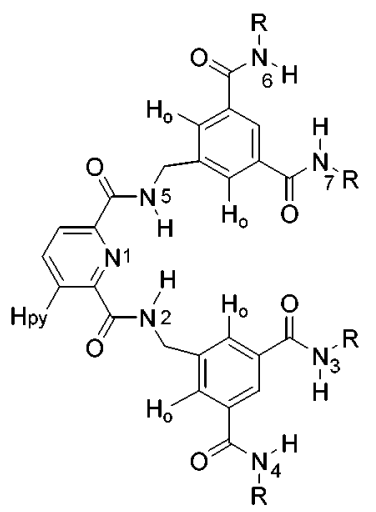<smiles>CC(C)C</smiles><smiles>[R]NC(=O)c1cc(CN)cc(C(=O)NC)c1</smiles><smiles>[R]NC(=O)c1cc(CNC(=O)c2ccccn2)cc(C(=O)N[R])c1</smiles>

$1 \mathrm{R}=$ cyclohexyl

$2 \mathrm{R}=(1-$ pyreny $\mid)$ methy $\mid$

$3 \mathrm{R}=(1-$ pyrenyl)methyl

a (i) $\mathrm{SOCl}_{2}, \mathrm{CH}_{2} \mathrm{Cl}_{2}$, rt; (ii) cyclohexylamine (for 1) or (1pyrenyl)methylamine hydrochloride (for 2), $\mathrm{Et}_{3} \mathrm{~N}, \mathrm{CH}_{2} \mathrm{Cl}_{2}$, rt; (iii) $\mathrm{H}_{2}, \mathrm{Pd} / \mathrm{C}, \mathrm{MeOH}$ (for 1); $\mathrm{PPh}_{3} / \mathrm{THF}$, then reflux in $\mathrm{THF} / \mathrm{H}_{2} \mathrm{O}$ (for 2 and 3); (iv) pyridine-2,6-dicarboxyl dichloride, $\mathrm{Et}_{3} \mathrm{~N}, \mathrm{CH}_{2} \mathrm{Cl}_{2}$, rt; overall yield: $1,75 \%$; 2, 66\%; (v) pyridine-2-carboxyl chloride, $\mathrm{Et}_{3} \mathrm{~N}, \mathrm{CH}_{2} \mathrm{Cl}_{2}$, rt; overall yield: $\mathbf{3}, 72 \%$.

scaffolds (Scheme 1). These compounds provide a delicate structural cleft with complementary amido groups that selectively hydrogen bonded with $\mathrm{PO}_{4}{ }^{3-}$ and $\mathrm{H}_{2} \mathrm{PO}_{4}{ }^{-}$ions. Compound 2 bearing the pyrene fluorophores also exhibits a unique sensing property when it binds with phosphate ion. ${ }^{8}$

The structural cleft is established by pyridine 2,6-biscarboxamide, which has a rigid conformation through the intramolecular hydrogen bondings. ${ }^{9}$ It is known that the two amido protons can serve as hydrogen-bond donors for acetate,,$^{10}$ nitrate, ${ }^{10}$ and fluoride ${ }^{11}$ ions. Thus, modification of pyridine-2,6-biscarboxamide by incorporating four additional amido groups would likely provide a pseudo-

(7) (a) Rudkevich, D. M.; Verboom, W.; Brzozka, Z.; Palys, M. J.; Stauthamer, W. P. R. V.; van Hummel, G. J.; Franken, S. M.; Harkema, S.; Engbersen, J. F. J.; Reinhoudt, D. N. J. Am. Chem. Soc. 1994, 116, 4341-4351. (b) Antonisse, M. M. G.; Reinhoudt, D. N. Chem. Commun. 1998, 443-448. (c) Chrisstoffels, L. A. J.; de Jong, F.; Reinhoudt, D. N. Chem. Eur. J. 2000, 6, 1376-1385.

(8) Pyrene has been used as fluorosence probes. For sensing acetate ion according to the mechanism of photoinduced electron transfer, see: (a) Nishizawa, S.; Kaneda, H.; Uchida, T.; Terame, N. J. Chem. Soc., Perkin Trans. 2 1998, 2325-2327. For sensing pyrophosphate-induced selfassembly of (guanidinium)methylpyrene, see: (b) Nishizawa, S.; Kato, Y.; Teramae, N. J. Am. Chem. Soc. 1999, 121, 9463-9464. For sensing Ca ${ }^{2+}$, $\mathrm{Cd}^{2+}$, and $\mathrm{Cu}^{2+}$ ions, see: (c) Yang, J.-S.; Lin, C.-S.; Hwang, C.-Y. Org. Lett. 2001, 3, 889-892.

(9) Yu, Q.; Baroni, T. E.; Liable-Sands, L.; Rheingold, A. L.; Borovik, A. S. Tetrahedron Lett. 1998, 39, 6831-6834.

(10) Bisson, A. P.; Lynch, V. M.; Monahan, M.-K. C.; Anslyn, E. V. Angew. Chem., Int. Ed. Engl. 1997, 36, 2340-2342.

(11) Kavallieratos, K.; Bertao, C. M.; Crabtree, R. H. J. Org. Chem. 1999, 64, 1675-1683.

tetrahedral cleft to hold phosphates. As shown in the scheme, 5-(azidomethyl)isophthalic acid ${ }^{12}$ was elaborated to $N, N^{\prime}$ dicyclohexyl-5-(aminomethyl)benzene-1,3-dicarboxamide, which coupled with pyridine-2,6-dicarboxyl dichloride to give the host molecule $\mathbf{1}$ in $75 \%$ overall yield. Compound $\mathbf{2}$ was similarly prepared in $66 \%$ yield by replacing cyclohexylamine with (1-pyrenyl)methylamine.

The X-ray analysis of $\mathbf{1}$ revealed that the conformation of pyridine 2,6-biscarboxamide was indeed confined by intramolecular hydrogen bondings with $\mathrm{N}(1) \cdots \mathrm{H}-\mathrm{N}(2,5)$ distances of $2.3 \AA$. The two phenyl rings were $6.73 \AA$ apart and almost in a parallel disposition, with a dihedral angle of $5.6^{\circ}$ (Figure 1). The pyridyl ring was perpendicular to the phenyl rings. This confined conformation thus constructed a preorganized structural motif for accommodation of the incoming phosphate ion.

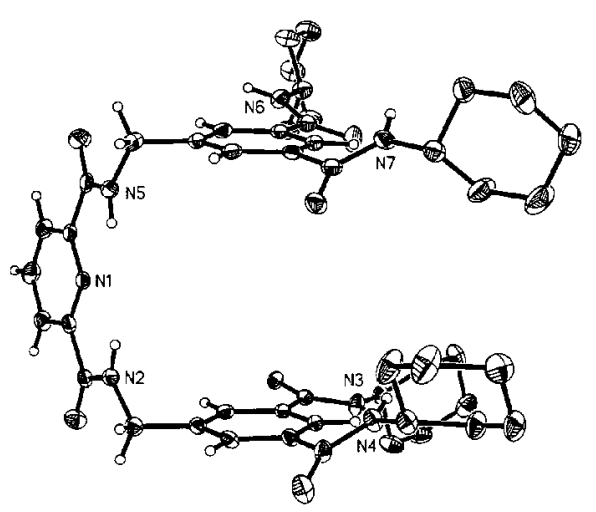

Figure 1. The crystal structure of compound 1 (side view). Incorporation of $\mathrm{MeOH}$ molecules and partial intercalation among molecules 1 was shown in the crystal packing (see Supporting Information).

The binding properties of $\mathbf{1}$ with a variety of anions were evaluated by the ${ }^{1} \mathrm{H}$ NMR studies in DMSO- $d_{6}$ solutions. Pertinent protons of $\mathbf{1}$ showed significant chemical-shift changes upon addition of tetrabutylammonium dihydrogen phosphate, for example, a $0.98 \mathrm{ppm}$ downfield shift of $N_{2}, N_{5^{-}}$ $\mathrm{H}, 0.27 \mathrm{ppm}$ downfield shift of $N_{3}, N_{4}, N_{6}, N_{7}-\mathrm{H}$, and $0.16 \mathrm{ppm}$ downfield shift of phenyl protons $\mathrm{H}_{\mathrm{o}}$ were observed in the presence of 4 equiv of $\left(\mathrm{Bu}_{4} \mathrm{~N}\right)^{+} \mathrm{H}_{2} \mathrm{PO}_{4}{ }^{-}$. The 1:1 complexation stoichiometry of receptor 1 with $\mathrm{H}_{2} \mathrm{PO}_{4}{ }^{-}$was confirmed by a continuous variation method (Job plot). ${ }^{13}$ The similar NMR changes also occurred when $\mathbf{1}$ was treated with tris(tetrabutylammonium)phosphate $\left(\mathrm{Bu}_{4} \mathrm{~N}^{+}\right)_{3} \mathrm{PO}_{4}{ }^{3-}$. These experiments indicated that the complexes $1 \cdot \mathrm{H}_{2} \mathrm{PO}_{4}{ }^{-}$and $\mathbf{1} \cdot \mathrm{PO}_{4}{ }^{3-}$ might be formed via hydrogen bondings with the six amido protons. Compound $\mathbf{1}$ also formed a 1:1 complex with $\mathrm{CH}_{3} \mathrm{CO}_{2}{ }^{-}$in a relatively weak binding. The association constants $K_{\mathrm{a}}$ and free energy data for acetate and phosphate ions were collected in Table 1.

(12) Dimick, S. M.; Powell, S. C.; McMahon, S. A.; Moothoo, D. N.; Naismith, J. H.; Toone, E. J. J. Am. Chem. Soc. 1999, 121, 10286-10296.

(13) Connors, K. A. Binding Constants; Wiley: New York, 1987. 

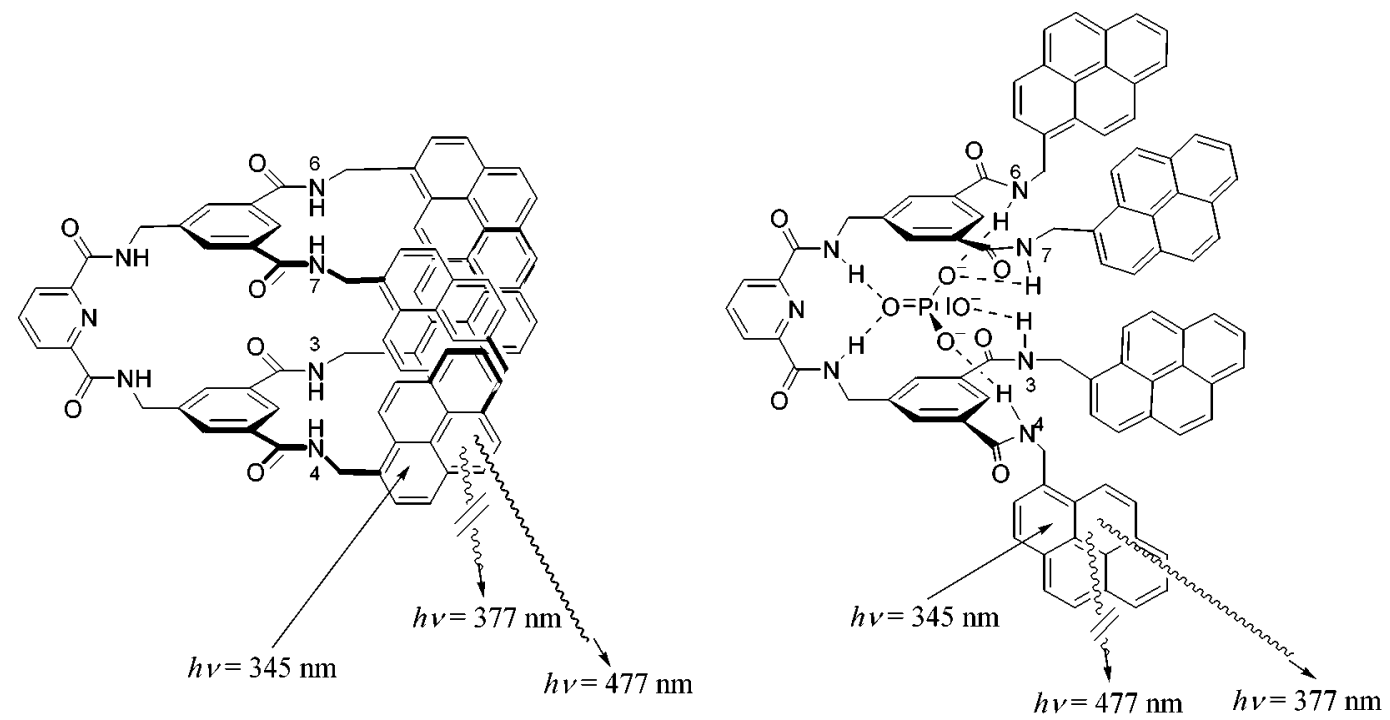

Figure 2. The proposed models for fluorescence change before and after complexation of compound 2 with $\mathrm{PO}_{4}{ }^{3-}$.

Unlike the previous report ${ }^{10}$ on the binding of pyridine 2,6-biscarboxamide with $\mathrm{NO}_{3}{ }^{-}$, compound 1 did not bind effectively with this anion. Neither $\mathrm{Br}^{-}, \mathrm{I}^{-}, \mathrm{SCN}^{-}, \mathrm{ClO}_{4}^{-}$, nor $\mathrm{HSO}_{4}{ }^{-}$ions showed appreciable binding with $\mathbf{1}$. The neutral amido groups of $\mathbf{1}$ might not interact effectively with the anions of low basicity such as $\mathrm{Br}^{-}, \mathrm{I}^{-}, \mathrm{SCN}^{-}, \mathrm{NO}_{3}{ }^{-}$, $\mathrm{ClO}_{4}^{-}$, and $\mathrm{HSO}_{4}^{-}$. The structural complementarity was another important factor to account for the effective hydrogen bondings. Thus, molecule $\mathbf{1}$ with a pseudo-tetrahedron cleft would bind preferably with $\mathrm{H}_{2} \mathrm{PO}_{4}{ }^{-}$and $\mathrm{PO}_{4}{ }^{3-}$ of tetrahedral geometry but not with spherical (e.g., $\mathrm{Br}^{-}$), linear (e.g., $\mathrm{SCN}^{-}$), or planar (e.g., $\mathrm{NO}_{3}^{-}$) ions.

By replacing the cyclohexyl groups in $\mathbf{1}$ with 1-pyrenylmethyl groups, compound $\mathbf{2}$ served as a selective chemosensor for phosphates. ${ }^{14}$ The pyrene rings were annexed to the terminals to avoid changing the cleft shape. The association constant of $2 \cdot \mathrm{H}_{2} \mathrm{PO}_{4}^{-}$was determined to be $1374 \mathrm{M}^{-1}$ in DMSO- $d_{6}$ by ${ }^{1} \mathrm{H}$ NMR titration method (Table 1 ). This value was even higher than that for $\mathbf{1} \cdot \mathrm{H}_{2} \mathrm{PO}_{4}^{-}\left(K_{\mathrm{a}}=549 \mathrm{M}^{-1}\right)$. Receptor 2 also had a better $\mathrm{H}_{2} \mathrm{PO}_{4}{ }^{-} / \mathrm{CH}_{3} \mathrm{CO}_{2}{ }^{-}$selectivity $\left[K_{\mathrm{a}}\left(\mathrm{H}_{2} \mathrm{PO}_{4}^{-}\right) / K_{\mathrm{a}}\left(\mathrm{CH}_{3} \mathrm{CO}_{2}^{-}\right)=5.75\right]$ by comparison with that for receptor $1\left[K_{\mathrm{a}}\left(\mathrm{H}_{2} \mathrm{PO}_{4}^{-}\right) / K_{\mathrm{a}}\left(\mathrm{CH}_{3} \mathrm{CO}_{2}^{-}\right)=3.45\right]$.

The UV-vis spectrum of $\mathbf{2}$ in anhydrous THF showed absorptions at $\lambda_{\max }=277$ and $345 \mathrm{~nm}$ at a concentration of $1 \times 10^{-6} \mathrm{M}$. In the fluorescence spectrum, the monomer

Table 1. Association Constants $K_{\mathrm{a}}\left(\mathrm{M}^{-1}\right)$ of Receptors 1 and 2 with Anions in DMSO- $d_{6}$

\begin{tabular}{|c|c|c|c|c|}
\hline \multirow[b]{2}{*}{ aniona } & \multicolumn{2}{|c|}{ receptor $\mathbf{1}$} & \multicolumn{2}{|c|}{ receptor $\mathbf{2}$} \\
\hline & $\begin{array}{c}\mathrm{K}_{\mathrm{a}} \\
\left(\mathrm{M}^{-1}\right)^{\mathrm{b}}\end{array}$ & $\begin{array}{c}-\Delta G_{300} \\
(\mathrm{~kJ} / \mathrm{mol})^{\mathrm{c}}\end{array}$ & $\begin{array}{c}K_{a} \\
\left(M^{-1}\right)^{b}\end{array}$ & $\begin{array}{c}-\Delta G_{300} \\
(\mathrm{~kJ} / \mathrm{mol})^{c}\end{array}$ \\
\hline $\begin{array}{l}\mathrm{AcO}^{-} \\
\mathrm{H}_{2} \mathrm{PO}_{4}^{-}\end{array}$ & $\begin{array}{l}159 \\
549\end{array}$ & $\begin{array}{l}12.6 \\
15.7\end{array}$ & $\begin{array}{r}239 \\
1374\end{array}$ & $\begin{array}{l}13.7 \\
18.0\end{array}$ \\
\hline
\end{tabular}

${ }^{a} \mathrm{Bu}_{4} \mathrm{~N}^{+}$as the counterion. ${ }^{b}$ The average value of two independent titrations at $300 \mathrm{~K} .{ }^{c}-\Delta G_{300}=R T \ln K_{\mathrm{a}}$. emission appeared at $\lambda_{\max }=377$ and $397 \mathrm{~nm}$, whereas the excimer emission appeared at $\lambda_{\max }=477 \mathrm{~nm}$. The excimer emission was resulted from the intramolecular excimer, rather than intermolecularly, as indicated by the dilution experiments at different concentrations $\left(5 \times 10^{-},{ }^{6} 1 \times 10^{-}, 65 \times\right.$ $10^{-7}$, and $1 \times 10^{-7} \mathrm{M}$ ), in which the intensities of fluorescence of monomer and excimer decreased simultaneously on dilution.

To discern which pair of pyrene rings were responsible for the excimer emission, the one-arm analogue 3 was prepared as a control molecule by condensation of pyridine2-carboxyl chloride with $N, N^{\prime}$-di(1-pyrenylmethyl)-5-aminomethyl-1,3-benzenedicarboxamide (Scheme 1). Compound 3 in THF solution at $1 \times 10^{-6} \mathrm{M}$ concentration showed only monomer emissions but no excimer emission. Upon addition of $\mathrm{H}_{2} \mathrm{PO}_{4}{ }^{-}$to 3 , the chemical-shift change of $N_{3}, N_{4}, N_{6}, N_{7}-\mathrm{H}$ was much more prominent than that of $N_{2}, N_{5}-\mathrm{H}$, indicating

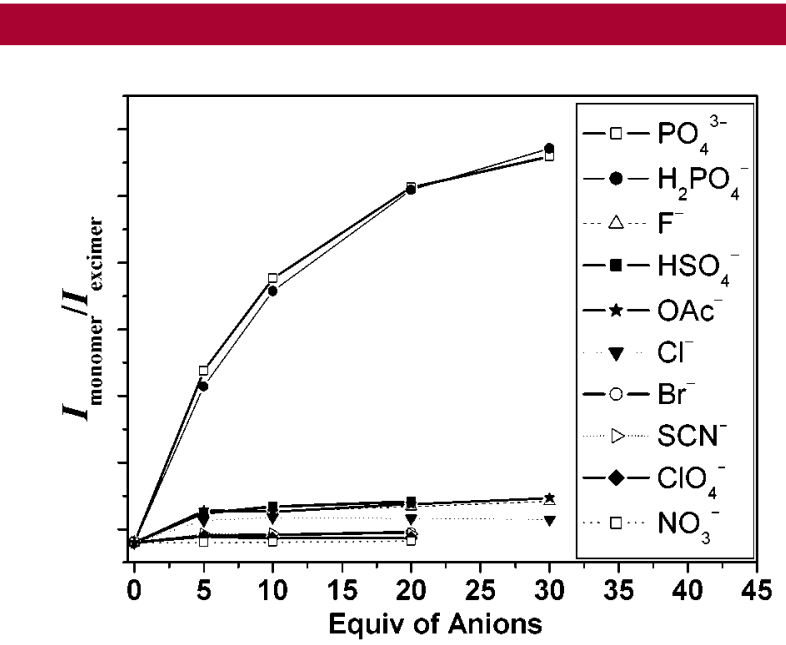

Figure 3. Fluorescence titration of $\mathbf{2}$ with various anions in THF. The binding strength can be inferred from the intensity ratio of the pyrene monomer to the excimer emission. 

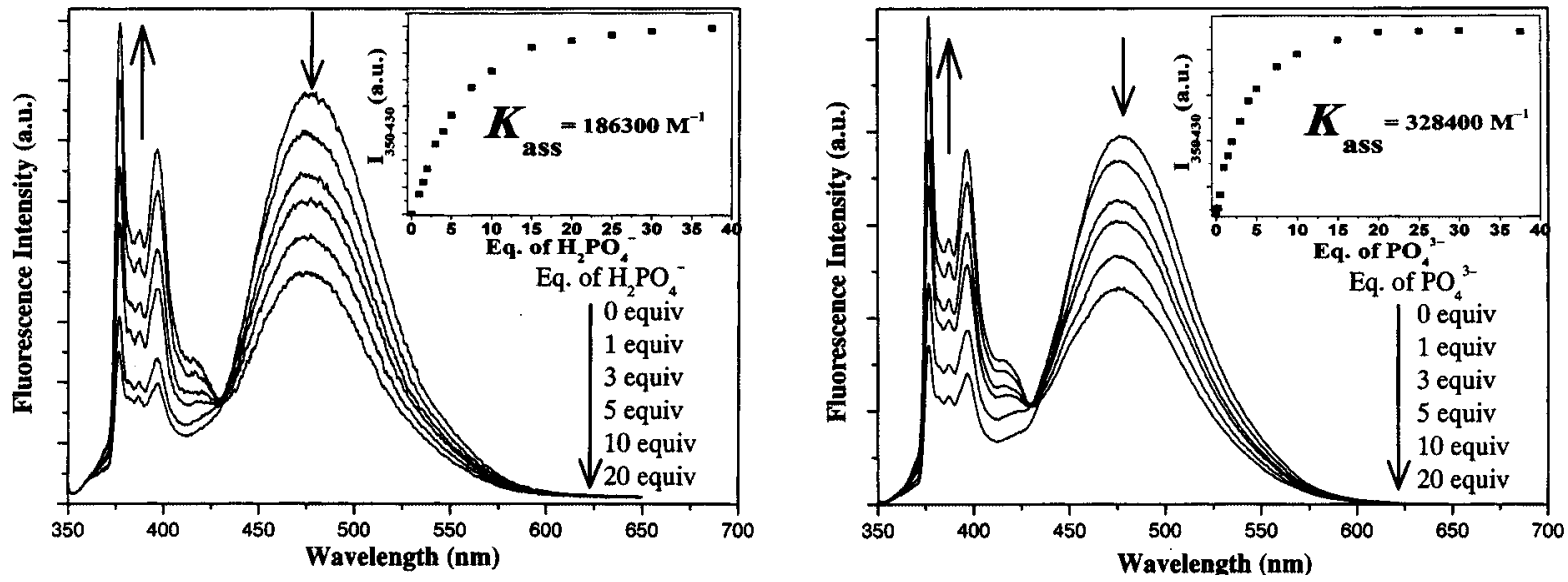

Figure 4. Fluorescence spectra of 2 with $\mathrm{Bu}_{4} \mathrm{~N}^{+} \mathrm{H}_{2} \mathrm{PO}_{4}{ }^{-}$(left) and $\left(\mathrm{Bu}_{4} \mathrm{~N}^{+}\right)_{3} \mathrm{PO}_{4}{ }^{3-}$ (right). $\left[R_{0}\right]=1 \times 10^{-6} \mathrm{M}$ in $\mathrm{THF}(2 \mathrm{~mL})$.

the $3 \cdot \mathrm{H}_{3} \mathrm{PO}_{4}{ }^{-}$complex was formed with a binding mode different from that of $\mathbf{1} \cdot \mathrm{H}_{2} \mathrm{PO}_{4}{ }^{-}$or $\mathbf{2} \cdot \mathrm{H}_{2} \mathrm{PO}_{4}{ }^{-}$complexes. By ${ }^{1} \mathrm{H}$ NMR titration, the association constant of $\mathbf{3} \cdot \mathrm{H}_{2} \mathrm{PO}_{4}{ }^{-}$was determined to be $198 \mathrm{M}^{-1}$ in DMSO- $d_{6}$, much smaller than that of $2 \cdot \mathrm{H}_{2} \mathrm{PO}_{4}^{-}\left(K_{\mathrm{a}}=1374 \mathrm{M}^{-1}\right)$.

Thus, the excimer emission of compound 2 could be attributable to the excimer formed by the pair of $N_{3^{-}}$and $N_{6}-\mathrm{CH}_{2}$-pyrenes (or $N_{4}$ - and $N_{7}-\mathrm{CH}_{2}$-pyrenes), rather than the pyrene rings on the same sidearm. This uncommon organized conformation of $\mathbf{2}$ might be partly due to the $\pi-\pi$ stacking of pyrene rings (Figure 2).

The sensing properties of compound 2 with various anions $\left(\mathrm{F}^{-}, \mathrm{Cl}^{-}, \mathrm{Br}^{-}, \mathrm{SCN}^{-}, \mathrm{AcO}^{-}, \mathrm{NO}_{3}^{-}, \mathrm{ClO}_{4}^{-}, \mathrm{HSO}_{4}^{-}, \mathrm{H}_{2} \mathrm{PO}_{4}^{-}\right.$, and $\mathrm{PO}_{4}{ }^{3-}$ ) were investigated by fluorescence titration studies (Figure 3). It appeared that the conformation of $\mathbf{2}$ only changed substantially on binding with phosphate ions.

A typical fluorescence titration curve of sensor 2 (in THF) with phosphates (Figure 4) was derived from the experiments with portionwise additions of $\mathrm{H}_{2} \mathrm{PO}_{4}{ }^{-}$or $\mathrm{PO}_{4}{ }^{3-}$ [1-37.5 equiv of $\mathrm{Bu}_{4} \mathrm{NH}_{2} \mathrm{PO}_{4}$ or $\left(\mathrm{Bu}_{4} \mathrm{~N}\right)_{3} \mathrm{PO}_{4}$ in THF/CHCl $\left.(1: 1)\right]$. In agreement to our prediction, the ratio of excimer emission to monomer emissions decreased as the amounts of anion increased. An isoemissive point occurring at $430 \mathrm{~nm}$ that supported only one type of complexation (2.phosphate) involved. The association constants in THF were deduced to be $186300 \pm 16200$ and $328400 \pm 19200 \mathrm{M}^{-1}$ for $2 \cdot \mathrm{H}_{2} \mathrm{PO}_{4}{ }^{-}$and $\mathbf{2} \cdot \mathrm{PO}_{4}{ }^{3-}$, respectively. The sensing mechanism appeared to have phosphate ion encapsulated into the core of the cleft via six hydrogen bonds (Figure 2) ${ }^{15}$ The binding of one-arm compound 3 with $\mathrm{H}_{2} \mathrm{PO}_{4}{ }^{-}$is relatively weak as it cannot provide six hydrogen bondings. Formation of the

(14) For application of anion recognition in sensors, see: (a) Snowden, T. S.; Anslyn, E. V. Curr. Opin. Chem. Biol. 1999, 3, 740-746. (b) Beer, P. D.; Gale, P. A. Angew. Chem., Int. Ed. 2001, 40, 486-516. For use of pyrene as the fluorophore in cation sensing, see: (c) Jin, T.; Ichikawa, K.; Koyama, T. Chem. Commun. 1992, 499-501. (d) Takeshita, M.; Shinkai, S. Chem. Lett. 1994, 125-128. (e) Diamond, D.; McKervey, M. A. Chem. Soc. Rev. 1996, 15-24. (f) Jin, T. Chem. Commun. 1999, 2491-2492. For use of pyrene as the fluorophore in barbital sensing, see: (g) Aoki, I.; Harada, T.; Sakaki, T.; Kawahara, Y.; Shinkai, S. Chem. Commun. 1992, 1341-1345. (h) Aoki, I.; Kawahara, Y.; Sakaki, T.; Harada, T.; Shinkai, S. Bull. Chem. Soc. Jpn. 1993, 66, 927-933. intramolecular excimer of $\mathbf{2}$ requires an orientation of pyrene rings in close proximity. The pyrene rings would be pushed apart on complexation with phosphate ion to disfavor the excimer formation. The $N_{3} / N_{6}$ and $N_{4} / N_{7}$ pyrene pairs were thus segregated to reduce the excimer emission, accompanied by increase of the monomer emissions. ${ }^{16}$

In summary, we have designed a new type of phosphate receptor with unique recognition and sensing properties. Receptors $\mathbf{1}$ and $\mathbf{2}$ have well-defined structures for efficient and selective complexation with phosphates in 1:1 binding stoichiometry. Although the binding of $\mathbf{1}$ and $\mathbf{2}$ with phosphates is not extremely strong, the binding selectivity is very high by comparison with other anions (e.g., halide, thiocyanate, acetate, nitrate, perchlorate, and sulfate ions). Addition of phosphate causes a simultaneous change of the monomer and excimer emissions of $\mathbf{2}$. This fluorescence change can possibly be utilized in diagnostic devices for the measurement of phosphate concentrations, even in the presence of other anions. Indeed, our preliminary experiments indicated that receptor 2 , in the presence of excess $\mathrm{F}^{-}$or $\mathrm{AcO}^{-}$ions (50 equiv), showed a significant fluorescence change upon addition of $\left(\mathrm{Bu}_{4} \mathrm{~N}^{+}\right)_{3} \mathrm{PO}_{4}{ }^{3-}$.

Acknowledgment. We thank the National Science Council for financial support and the Instrumentation Center (National Taiwan University) for X-ray analysis.

Supporting Information Available: The detailed experimental procedures, spectral data, NMR spectra of selected compounds, and NMR and fluorescence titration curves, as well as the crystal data, bond distances and bond angles of compound $\mathbf{1}$. This material is available free of charge via the Internet at http://pubs.acs.org.

\section{OL0171564}

(15) A molecule containing two 2,6-diaminopyridine units linked through an isophthalate spacer forms six hydrogen bonds with barbiturte substrates as shown by the NMR and X-ray analyses. See: Chang, S. K.; Van Engen, D.; Fan, E.; Hamilton, A. D. J. Am. Chem. Soc. 1991, 113, 7640.

(16) For a general review of guest molecule induced fluorescence change, see: de Silva, A. P.; Gunaratne, H. Q. N.; Gunnlaugsson, T.; Huxley, A. J. M.; McCoy, C. P.; Rademacher, J. T.; Rice, T. E. Chem. Rev. 1997, 97, $1515-1566$. 